\title{
TELLING STORIES: LIFE HISTORIES, ILLNESS NARRATIVES, AND INSTITUTIONAL LANDSCAPES
}

\author{
A Catalogue of his sins, eh? Is that what you mean? \\ asked Orlick. \\ Do you understand what I mean? asked Furriskey with \\ solicitude. \\ I think I do, mind you. DRUNKENNESS, was addicted \\ to. CHASTITY, lacked. I take it that's what you had in \\ mind, Mr. Furriskey? \\ That sounds very well gentlemen, said Lamont, very \\ well indeed in my humble opinion. It's the sort of queer \\ thing they look for in a story these days. Do you know? \\ (Flann O'Brien, At Swim-Two-Birds, p. 245).
}

\section{INTRODUCTION}

The following transcript is at once part of a life history as well as what we have come to call in medical anthropology an "illness narrative." I collected it during my fieldwork in Ireland in 1988-1990 from a man whom I am calling for the purposes of this paper Finbar McTernan. This text is the fruit of my attempt to elicit a story of a chronic condition, from a life that has, for better or worse, been defined by both this condition and the struggle against its label chewing into the rest of an existence.

This story develops from a complicated life at the margins - at the margins of society, of economic success, ultimately of health itself. It is also marginal in another sense. It is a narrative from an articulate person with schizophrenia - a species that much current medical speculation on the subject is loath to imagine. The subject at once acknowledges his (occasionally) profoundly altered phenomenological sense of himself and his surroundings, while struggling against his engulfment by a body of knowledge, psychiatry, which, in his eyes, sees little of him beyond an illness label.

In this paper, I develop the idea that a narrative of a chronic condition is not simply a story of personal experience. It is, rather, deeply embedded within various institutional structures that influence its production as a 
story. As part of my interest in the embeddedness of narrative within institutional frameworks, I also want to focus the reader's critical attention on my own use of a fragment of a transcript from an open-ended interview in the production of a knowledge-product in medical anthropology.

\section{NARRATIVES IN MEDICAL ANTHROPOLOGY}

Clearly, I frame this piece initially as "a kind of story." As such, this paper's theoretical roots reach into a body of work on "narrative" that has enjoyed substantial growth in the past fifteen years. Important work on this subject has emerged in literary criticism and philosophy (Iser 1978; Ricoeur 1981, 1984; Derrida 1978, 1981; Lyotard 1984 among many others), in psychology and psychoanalysis (Bruner, J. 1986), history (White 1981), and anthropology (Good 1994; Mattingly 1994; Kleinman 1988a, 1988b; Abu-Lughod 1993; Bruner, E. 1984; Turner 1981, 1986 among many others). ${ }^{1}$ How people tell stories, and why these stories are aesthetically, rhetorically, and/or technically effective has become a respectable academic topic. Indeed, narrative is one of only a handful of key terms in social analysis that have been fruitfully pursued from a wide variety of different disciplinary perspectives. This interest is hardly surprising given the centrality of texts (often first-person accounts) collected from subjects in the interpretive social sciences.

In the face of this expanding area of scholarship, I will restrict myself in this paper to one main theme that might be called "the conditions of narrative production" in medical anthropology. Specifically, I am interested in the relationship between the production and the consumption of stories about chronic conditions as they relate to what I am calling "institutions." To map out this issue, I will need to review a bit of personal history.

I have spent the last two years in fairly close contact with people who, in part, write grants to medically-oriented funding agencies for a living, presenting and representing medical anthropology to other, potentially hostile, disciplines as worthy of funding dollars for psychosocial research in a shrinking grant pool. During this same period, I have also served on the Central Office Research Review Committee for the Department of Mental Health of the Commonwealth of Massachusetts, in whose meetings I have defended the value of anthropological methods and ways of thinking to my more quantitatively-inclined colleagues. I have noticed certain connections between the theoretical justifications of the grants that I have read and my own protestations in committee. Such justifications of non-quantitative psychosocial projects argue for an intrinsic value in the "qualitative data" generated by social scientists (specifically anthropologists), which tends 
to translate in such settings as "narrative data gathered from open-ended interviews." I think that these experiences, while hardly representing the acme of theorizing on narrative in medical anthropology, have something to say about models of narrativity at large in the sub-discipline. These models form a frame for my own retextualizing of a fragment of an interview within the context of an academic paper.

Such justifications, for example, either explicitly or implicitly insist on the value of texts generated in the process of getting a person's story from that person. "You [meaning anthropologists] tap the source of experience," said one of the MDs with whom I work on committee. He was presenting to me his understanding of "qualitative data," at once conceding a certain closeness of the anthropologist to "real life," while critiquing the inherent conceptual messiness of this neighborliness. While many of our more quantitative colleagues find our explanations about what exactly we do with such texts during the course of our analysis somewhat opaque, if not occasionally occult, there is still a certain respect generated in them for the supposed proximity of the anthropologist to the raw experience of real life concentrated in "a story" that wins for us what (admittedly limited) influence we command in such settings.

The sense of narrative that emerges in this setting is captured by the following model.

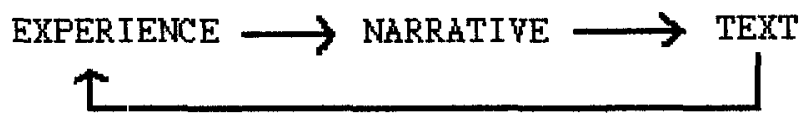

INTERPRETATION

In this model experience is the wellspring of narrative which is transcribed in a text from which a process of interpretation can lead us back to the original experience. Few researchers working with something like this model pretend to capture an event through a "transparent" text, but many do seem to argue that, insofar as an individual phenomenology undergirds a narrative, this experience is able to be captured through a process of the qualitative analysis of particular transcripts. Such an understanding of narrative in both the clinical encounter and in more general contexts poses some serious theoretical issues for medical anthropology.

\section{INSTITUTIONS}

My basic suggestion in this paper is that making a larger analytical place for a concept of "institution" in our understanding of narratives of "personal" experience is a strategy for knitting together the presence 
of agency, meaning, and power in the production of stories. This extrasubjective aspect to the production of an illness narrative exists beyond the patient/therapist/family context that has been fruitfully explored in recent years (Mishler 1986a, 1986b; Mattingly 1994; DelVecchio-Good et al. 1994; Good and DelVecchio Good 1994 among others). While these and other dialogical approaches to narrative have detailed the micro-contexts of stories in medical contexts, the current lack of an institutional focus in our increasingly sophisticated theories about the formation and dissemination of illness stories in medical anthropology masks the fact that so much of the discipline operates in expressly or covertly institutionalized settings.

By "institution" I do not simply mean a particular building or even a self-evident social network, but rather, following the Latin root of the word "institute," instituere, "to set up," I mean a structure (physical, conceptual or both) that "sets up" discourse and practice. This definition is close to that found in the work of Jean-François Lyotard.

[A]n institution differs from a conversation in that it always requires constraints for statements to be declared admissible within its bounds. The constraints function to filter discursive potentials ... They also privilege certain classes of statements (sometimes only one) whose predominance characterizes the discourse of the particular institution: there are things that should be said, and there are ways of saying them ... Bureaucratization is the outer limit of this tendency. [Lyotard 1984: 17]

I am defining institutions, then, as bundles of technologies, narrative styles, modes of discourse, and, as importantly, erasures and silences. Culturally and historically situated subjects produce and reproduce these knowledges, practices, and silences as a condition of being within the orbit of the institution. This definition of institution focuses our attention on the ability of the institution to define and constitute as well as on the silences and erasures that provide the persuasive force for such definitions. As such, my use of the term "institution" has resonances with the concept of "field" and associated notions like "symbolic violence" that appear in the writings of Bourdieu $(1984,1991)$. This way of conceptualizing institutions, I believe, gives us an appreciation of such organizations that goes beyond the idea that the main function of an institution is to control its inmates and reproduce itself (Goffman 1961) or to Douglas' notion that the main function of an institution is to name (Douglas 1987).

A broader, more discursive concept of institution is a strategy that allows us to begin to outline the relationship between system and innovation, power and agency, and structure and contingency in the construction of stories. Rather than looking at institutions as unproblematic envelopes around more central narrative information and rhetorical strategies, I want to think of institutions as helping to constitute stories as well as being sites 
of narrative productions. The problem of institution, then, necessarily bears on our thinking about the relationship between texts, narratives, practices, and discourses. The focus on institutions also emphasizes the fact that there are institutional assumptions that both constitute and help to constrain the production of knowledge in medical anthropology.

The model of the relationship between text, narrative, experience, and institution that I am proposing, then, looks something like this.

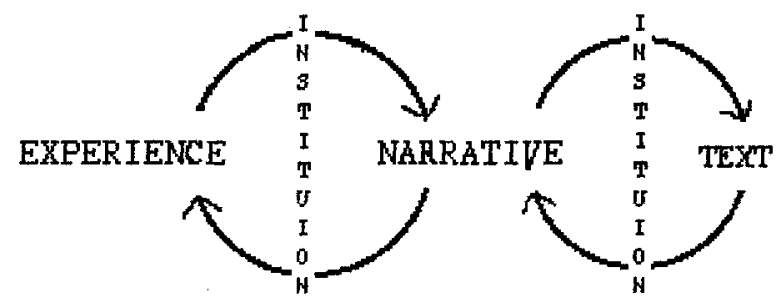

I think that there are a number of ways that this sort of model advances a theory of narrative in medical anthropology. First, it problematizes the relationship between "experience" and the development of a story about that experience in such a way as to focus our attention on the specific circumstances, that is, the social field in which narratives are developed and deployed. This way of looking at narrative does not invalidate the usefulness of the notion of "personal experience" for medical anthropology, but it does distribute the responsibility for the production of this experience to presences beyond an experiencing self. Second, this model stresses the importance of textual production within an anthropological analysis. This subject is too often glossed in medical anthropology as merely the development of qualitative data from "unstructured" interviews. While this theme of institutional constraint of my own narrative production will be impossible to explore fully in the analysis, I will be referring to it now and again as a presence in, and potential critique of, my own writing.

\section{FINBAR MCTERNAN: BACKGROUND}

I first introduced myself to Finbar McTernan after a talk he gave to an allday meeting in Dublin under the auspices of the Schizophrenia Association of Ireland (SAI), an organization that is the rough equivalent of the National Alliance for the Mentally Ill (NAMI) in the United States. My initial impression of him was that he was an articulate, if disheveled, individual, fairly anti-psychiatric in his mental health beliefs, whose Northern accent, softened only slightly by nearly a decade of residence in Dublin, imparted a certain forcefulness to his speech. Over the coming months, we became friends with one another, meeting in the city center for the occasional cup 
of tea, for formal interviews at my place, and interacting around monthly meetings of sufferers of schizophrenia organized into a Support Group under the auspices of the SAI.

Finbar is a middle-aged man diagnosed with schizophrenia who has spent much of his adult life in contact with the mental health services both in the North and in the Republic of Ireland. He was born in 1946 just outside the town of Omagh in the county of Tyrone, the fifth of nine children of a postman. He was educated at a Catholic school in a relatively severe environment by priests and Christian Brothers. He eventually went on to earn a degree at Queen's University, Belfast in pursuit of a career as a teacher at the secondary level. For Finbar, the thirteen years recounted below form the time frame of the most critical period of his life. They are part of a story about his journey from initial contact with institutional psychiatry to his definition as a chronic schizophrenic.

The main narrative line of the following text is deceptively simple. It is Finbar's answer to my question about how he was diagnosed with schizophrenia. At one level, then, it is an account of a career of a mental patient, a slow and conflicted connection over the course of thirteen years between a profoundly altered experience of self and reality and a knowledge-construct, schizophrenia, that, psychiatry insists, accounts for these altered perceptions and behavior through a model of "disease." Interspersed in this basic plot, however, are Finbar's reflections on his position in society, the nature of knowledge and morality, and the evident connections between even his most disordered sense of "reality" and the social life surrounding him.

F: When I first began having trouble, the general practitioner was consulted first. He recommended that I see a specialist. He probably wouldn't have said, "nerve specialist," but the people, my mother, and the older people, the people generally in the town, they talked about a "nerve specialist." That is when they mentioned it at all. A lot of the time they wouldn't have wanted to talk about it, because we talked about the "big house," you know, that is the asylum out the road.

It would only have been about a mile and a half outside the town, in fact, it now really [is] almost in the town. It was actually unusually close to the town, the Omagh [mental hospital]. Tyrone and Fermanagh: $T$ and $F$, they call it now, 
yeah. ${ }^{2} \mathrm{He}$ 's in the T and F. I think it's full of mostly alcoholics now.

J: So, it's mostly full of alcoholics now?

20

F: It is so. You know, I'm rather skeptical about "alcoholism" as a disease entity. I think there's a fair bit of what we call ... I don't know, "spoiling" yourself ... First of all you drink

25 yourself into a problem, then you get people to go and tell you you've got an illness, you know. It's great, you got it both ways, and then you can look down on schizophrenics. I used to find that the schizophrenics in the hospital were second-class

30 citizens. You were treated as a lunatic, you were shoved around, sometimes literally. But, the alcoholics, ... no problem. They were on no medications, no side-effects. They [went] on about there like kings of the castle, you know ...

35 We are in fact the lowest, we're on the lowest rung of society that there is. Because even mentally handicapped people are not in a comparable situation because they're supposedly kind of separated in a sense. People say well ... OK, they

40 don't understand, maybe, or they're not able to do certain things. But they probably get better treatment as such, you know, they're more appealing to people.

45 J: Uh huh.

F: People.... The attitude people have to lunatics or schizophrenics is that, you know, they're dangerous, they're sort of ... you know, they're

50 horrible. You know you hear some awful things said, in fact. I'm pretty angry about this guy Owen Harris of RTE, ${ }^{3}$ that's putting on a couple programs about manic depression. ${ }^{4}$

$55 \mathrm{~J}$ : Oh yeah.

F: My brother was watching one of the things he was 
on about that came on before. He [Owen Harris] was advertising it. And, he says - talking to John

60 Ogden, the pianist - you see, a famous pianist. He had a breakdown and was supposedly classified as manic-depression. He lives in a house separated from his wife by a kind of, some kind of, ... steel wall or something like that, or a steel partition, 65 and he must be violent, you see. So Harris says he's a complete [?]...

His approach to it is, you know, "Manicdepressives are all geniuses, and I'm a genius too because I'm a manic-depressive." He's blowing his

70 own trumpet, you know.

But, uh, he says, you see, ah, he says - John Ogden, John Ogden is a bit violent. He says, "Ogden must be a bit schizophrenic," he says, "Because manic-depressives are never violent." And 75 this is the kind of shit that's given publicity.

J: Really?

F: He's putting us down, and at the same time, he's 80 getting a program out of it, manic-depressive. And he's saying, "Manic-Depressives, you know, Beethoven was a Manic-Depressive." Everybody's a Manic-Depressive, you know. You're nobody if you're not a Manic-Depressive.

85

\section{$\mathrm{J}:$ [Laughs]}

F: It's the same as alcoholism. Brendan Kinelly, the poet, he writes in the Irish Times, "Alcoholism

90 is creative." Yeah, it's creative - it creates a bloody nuisance for people, especially when you come home and beat your wife, you know, that's creative all right.

I think if you, if you create a problem by

95 drinking and are told then that you're ill and that you deserve sympathy. I think that it's a wee bit much. Life is reward and punishment. If you're rewarded for behaving irresponsibly, you'll tend 
to, I think, inevitably, I think you'll tend to

100 sort of continue it. Get worse, maybe.

So, of course, it's a growth industry, too, because the doctors actually, they want more alcoholics. C'mon, you know, c'mon all in. There's plenty of space here for alcoholics. No

105 problem.

But I'm getting a bit off the point....

\section{J: That's all right.}

110 F: The thing is, ... I would like to find out something about that - the alcoholics. What exactly it is? You know ... the doctor is approaching something, and he's kind of saying, like all down the centuries, people have said, you

115 know, leaders and scientists, so-called scientists in those days, priests and whatever they might have been in the old societies. They say, "Look, the moon arises, and the moon is this sort of thing." They're kind of approaching an unknown quantity, 120 and they're saying that they know all about it, you know.

That's sort of saying, that's a ... [long pause] People say to you that they're experts, you know. "But, they are experts!" Certainly, they got the 125 power to put you away, to lock you up, and so on. But, I don't know if that means they're experts.

J: What happened after the General Practitioner?

130 F: Then, I was all right for a while. I actually started to teach. I was teaching for two years, in '68-'70. After that, I packed it in. I stopped the teaching. I left the job at the end of the school year in '70. And then I sort of did

135 nothing. I went to London, and then I came back. I was hanging about the house and that.

Then in '71 I got another ...

You see in these two times, '66 and '71, I wasn't actually diagnosed, as a ... I wasn't told I was 
140 schizophrenic. I didn't actually go "around the bend" as such. You know, I wasn't "mad" in the conventional sense of the word. I'd just get terrible restless, sort of agitated depression, that kind of thing, you know.

145

J: Yes.

F: Dr. MacDermot [a psychiatrist in Belfast], he came to me. He went to the house at that time to see me. He stayed about two minutes, you know ... He came in. I was sitting watching the TV. This was in '66, and he says, "Do you feel people are against you?" That was all he said. He never even said "Hello."

155 He said, "Do you feel people are against you?" I said, "Actually, I don't feel people are against me, as a philosophical proposition."

\section{J: [Laughs]}

160

F: I didn't want to go on and, like, develop it because, you know, doctors are usually very short on philosophy, I find. They kind of, you know, they don't like people philosophizing. But, uh. I

165 said that I got the impression that those faces on the TV there that are in the crowd, you know - it was a rugby match I was watching - are sort of hostile, you know. Well what it was, I thought the environment had become unpleasant, you know.

170 Everything was hard, harsh, you know. But, I wasn't deluded as such. I wasn't mad. I didn't think that the people were trying to kill me or anything. I just felt, it was almost, you can't It was a total altering of your perception. It's as if I was in this room, and I felt that you were sort of "looking at me" in a kind of critical way, or you thought I was no good, or something like that. You thought, you know, you're sort of despising me. 
As I say, it was a hostile environment. But, he [MacDermot] must have, he must have ... He gave me Largactil, he put me on bloody Largactil, you know. I didn't know these things. At that time I thought these are great things, they're gonna help you. I didn't know anything about side-effects. There was no information about side-effects in those days.

In fact, I remember saying to him, you know, Largactil. I said, "Is that Largactil you've got

190 me on?" And MacDermot sort of ...

He's very like Jack Palance, oddly enough. Honest to God, he was the spittin' image of Jack Palance. And, he says, he sort of smiled, you know, by the way like, "Oh, how did you come to

195 know the word Largactil?" You know what I mean like, sort of patronizing. I said, you know, "Is this Largactil that I'm on?" You know it was exactly, the way he did it, it was exactly, sort of, well you know. [He was saying] "Do not think."

200 "You shouldn't be talking about that, that's not your concern to be talking about it."

They want to keep everything that they have secret, you know, as part of the old routine. You know, like the astrologers or the Pharisees. You 205 come down the centuries, and ... As you come down the centuries, there has always been a group, a society that has been secret.

\section{J: Hmmm.}

F: I mean, I actually think that Jesus Christ was speaking against that type of thing when He said, like when He said to the Pharisees and different people, He would have said things like, "You make

215 burdens for the people's backs." And He said another time, "Because you say you can see, your sin remains." And, I take that to mean because you say you know it all, you're actually wrong. You're in error. You're committing a wrong on the people, 220 you know. 
J: Uh huh.

F: Then, until '77 I was OK. I was in the hospital in St. Patrick's till '71.' Then from '71-'77 I was OK. I was working in Belfast most of that time. Then from December of 1977, I went, you know, "'round the bend," as it were. I lost contact with reality. I had a real schizophrenic 230 episode. That's the word I prefer actually of all the terms that are used for, ... you know, having a "breakdown." I think having a breakdown is sort of bollixed. You'd think you were sort of collapsing into bits, you know.

J: [Laughs]

F: Strewn all over the floor you know. Yeah, there he is. He's had a breakdown, you know. There's

240 one bit of him over there, yeah. I say an "episode" because I think what it is, obviously, presumably, sparing the man above, you know. Maybe the man above knows more about it than I do, but uh. It obviously must be some kind of chemical change that comes over the brain where you see things in a different way. I mean it lasts, I think, for a certain time. Then, you know, rights itself again, for no apparent reason. I mean, uh .... I don't think that it has the remotest 250 connection with stress or anything else. I just think actually, as I said to you before, I think. ${ }^{6}$ I think it's a completely time-based thing.

There were things I thought about, though. When I was in, the day before I got into the hospital.

255 The night that I spent at my brother's house - I couldn't sleep, you know. I didn't sleep at all that night. I remember thinking the vans, the kind of lorries, just right beside the kind of main road. And I thought the lorries and the vans were 260 all full of dead bodies.

I remember thinking this now. It's kind of, ... It's like being actually in a sort of horror movie, 
you know, and watching it, and believing it, you know?

$\mathrm{J}$ : Yes.

F: Not just seeing it, and sort of laughing at it, or whatever. But being it, believing it. You sort

270 of think ... For some reason ... it was connected with The Troubles in a way. The Catholics were all being murdered, you know. You know I had this terrible thought of, sort of, extermination camps, you know ... This is the Final Solution type of 275 thing. Everything was horrible. You'd see something on the TV. It was sort of, you'd see something on the TV, and you'd think, ah ... It'd kind of remind you of Hitler, sort of like that. Things that you'd seen before. ... There seemed 280 to be a lot of cruelty about, you know. Again it was that hostile thing. It was well, you know, that I had before. But this time I was completely deluded, you know. It wasn't that I was able to rationalize anything. It was completely unsided 285 [one-sided?], you know.

And, I remember saying - when I got into the hospital eventually. My brother was with me, he brought me up to the hospital. It was quite near to where he lives.

290 I went into the ward. I was down on the ward, and I said, I says, I was saying, "Where's all my friends?" And I was sort of crying, or shouting. "Where's all my friends? Where's Rosemary?" "Where's ... Tom?" You see, these were fellas that 295 I worked with, people I worked with, the fella that I worked for, for a while, and all this. I didn't know where I was actually. I didn't actually know where I was, you know. It's funny how you're completely disoriented.

$\mathrm{J}$ : You knew your brother.

F: Oh yeah. I knew my brother all right, fair 
enough. You knew certain things. It's funny that

305 actually. If you could really remember. If you had a good memory and could remember exactly, it would be interesting to know, just what, how far it, the delusion, goes. And how far you're still "in touch" with reality. Because I obviously knew

310 my brother. I knew where I lived. I knew the name of the road. I knew the name of the hospital. I think I knew I was in the hospital all right, as far as I know. I used to always be sort of afraid of that place. I thought it was sort of a

315 depressing spectacle. It was one of the old asylum-type hospitals.

$\mathrm{J}$ : What was that [the hospital] like?

320 F: I left at the end of October. ${ }^{7}$ And then again in '79, I had another episode. In May '79. But this time it was mostly elation, you know. And, what Ruth O'Sullivan mentioned in that Irish Times article, ${ }^{8}$ about being "driven" from place to place, 325 you know. I had that. At one stage before I got into hospital that time, I walked all around Belfast, you know, from place to place. I used to walk.

I thought I kind of had a mission, you know,

330 somewhere to go. That's the way I was, I was completely "around the bend." I thought, you know ... I used to say things to people. I would say, - I went into the library and I was up a couple stairs, and this man come up to me and says 335 - and I said to him - I was kind of thinking about this Protestant/Catholic thing and all - and I says to him, "Don't forget that justice is a Roman word."

And he sort of, he never, you know, he didn't say, "You're mad" or something or "What are you talking to me for?" He says, "Yeah. It's Roman but not Italian."

[Laughs]

I think what he meant by that was that it was 
345 Roman, ancient Roman, but it wasn't connected with the pope, like.

J: Yeah.

350 F: He was getting in a point. I knew he was a Protestant, actually, because, ... I kind of knew him I think, actually. I had seen him before. But, ... [Laughs]. He didn't know me I think, you know. You'd speak to people on the street. I

355 remember saying to this woman, you know, to a traffic warden at night time, "I must get home to my flat," and so on. And she said, "What's wrong with you, love?" You know, she thought I was kind of a lost soul or something. She didn't know I was 360 mad.

And I ended up, and I ended up at that time, too, at The Martyr's Memorial Church, you know Paisley's business. ${ }^{9}$

365 J: Oh really?

F: Actually, there was a marriage or something going on, you know, at the time. And, I went up to the door, and there was this guy in a swallow tail 370 coat, you know, dress suit and all. And, ... I said to him - I was kind of again in a sort of a daze, you know - and I said, "I'm a Roman Catholic, and I want to see the Church." And he sort of didn't say anything, he just grabbed me by the arm, you 375 know. He steered me out to the, to the, you know, to the gate of the church. And I walked on.

J: Where did you go?

380 F: I resumed my march. And I remember actually that I used to, ... I had this, ... delusion at the time. I'd always been sort of thinking - at that time I had been reading a fair bit, a wee bit, of history, and I was thinking on this thing.

385 You see the Roman Empire and the British Empire, you see. Like the Roman Empire was like the 
Catholic Church, say, if you were a materialist, you could say that the Catholic Church was kind of the successor to the Roman Empire, took over from the Roman Empire. And the pope was kind of a Roman Emperor in a sense. And then the British kind of rebelled against it, like.

I was always looking for things. I got them out. There was things in Shakespeare. Someone says in 395 one of the historical plays, he says, "Britain is an Empire by itself, and we will nothing pay for wearing our own noses." ${ }^{10}$ In other words, like, they were going to set up in business for themselves, and break away. That's in effect what

400 happened. And then when they took over the role, eventually, of the Romans like being the world rulers. So I was preoccupied with this, so when I got mad, you see, it was all going over me head and all.

[Laughs]

There was a place in Belfast, Caesar's Palace, you see. One of these, ... there's a Caesar's Palace everywhere. One of these old places with slot machines. And I thought [laughs], I remember

410 thinking this had something to do with Caesar actually, you know; it was Roman. I said, "The Romans are ..." - I remember thinking, "The Romans are setting up in business," you know. There must be something going on.

415 And then - I used to walk along those security gates $^{11}$ all the time, there used to be a lot of soldiers, you'd see a lot of British soldiers hanging about, you see. I used to be going along like this, you see. You know in these old

420 Hollywood Roman movies, they would have the salute like this you know [demonstrates]. And, here was me going along - I had some idea you see that kind of the Romans and the British were kind of ... cooperating, ... I don't know what, it was kind of mixed up. I was going along like this you see, going like this [demonstrates] to the soldiers.

[Laughs]

I don't know what they made of this, you know. 
THE USES OF STORY

This text answers to many of the definitions that we have developed in anthropology and other disciplines around the notion of "story" or "narrative." It develops a plot within a temporal frame, it is narrated by an agentive subject who has a sense for his audience, and the main character (the narrator) confronts, and must adapt to, the intentions of other characters in the story (Bruner 1986).

This story also clearly relates what we might call personal experience. Finbar gives us a rich sense of what it means to feel socially marginal or that one's everyday reality is slipping away or changing in an extraordinary fashion. He articulates a rich phenomenology of the emotions of abandonment, terror, amusement, suspicion, and hostility.

Nonetheless, this story is also inexorably bound up with an institutional topography. We cannot understand the narrative flow of this story - not its structure, not its humor, not its pathos - without understanding the institutional channels ${ }^{12}$ that at once restrict the freedom of, and give shape to, indeed make possible, the creation of this particular story. Within Finbar's story, for example, this topography most clearly entails the structure of psychiatric knowledge and praxis, the institution of the Asylum. The technologies, objects of knowledge, practices and erasures that are the stuff of psychiatric praxis take up most of the first part of this fragment (up to Line 224). Finbar, however, develops critiques about this institution through other forms of what we can only call "institutionalized" knowledge. At times, for example, he gives voice to the authority of a morality clearly connected to the Catholic Church (e.g., the deserving vs. the undeserving sufferer as well as the idea that suffering conveys authority on the sufferer). The latter half of this text also references, and plays with, alternately with pathos and humor, the institutionalized violence of the sectarian divide in his adopted home of Belfast at the time of his most severe psychotic breaks. It is on and through this landscape that Finbar as narrator fleshes out his seemingly personal experience of illness and amelioration, as well as his own annotations on his life.

\section{EMPLOTTERS AND EMPLOTMENTS}

In addition to these qualities, this text is also clearly made from the perspective of a temporal divide in which institutional psychiatry has a pride of place. At the time of the telling, for example, Finbar has already been, to use a phrasing popular with much of medical anthropology, "therapeutically" (or at least "diagnostically") emplotted (Mattingly 1994; DelVeccio-Good 1994). ${ }^{13}$ The narrative trajectory on which he has been sent is one of 
chronicity and despair. His reflections are made from the other side of an historical barrier between the past and the present defined by the presence of institutional psychiatry and its technologies (medication and visits by a psychiatrist). ${ }^{14}$ Although he often jumps around in the temporal sequence of his life, employing knowledge gained during a long career as a mental patient to comment on certain portions of the narrative, the contact with a psychiatrist in 1966 and with hospitalization in 1971 and the two episodes of hospitalization in 1977 and 1979 - form the beginning and the conclusion to this particular story that establishes his identity as a mental patient.

The force of diagnostic emplotment is most evident in the frame for which Finbar initially groped to put upon our conversation. Finbar starts his discussion of his association with a mental illness in the genre of a medical history. He begins by relating the seeking of care for a specific experience. He may have felt that this conversation was to be a replay of a repeating conversation that he has been having with various health professionals for more than twenty years (Lines 1-8). This connection to a label reflecting his disordered interiority is both a dominant part of his identity and the main battle line within his life story between an identity and institutional power.

The genre of medical history, however, is rapidly abandoned as Finbar develops the narrative. His reference to the local term for psychiatrist, "nerve specialist," for example, points to a reinterpretation of the notion of specialty that I have explored elsewhere. Indeed, I have argued that terms like "nerve specialist," the "T and F" and the "big house"15 are parts of various local projects dedicated to the domestication of the asylum in rural Ireland (Saris 1994). Through the use of such terms, Finbar clues us in that both the Asylum and the knowledge that it generates are open to challenge and reinterpretation.

Very early on in this transcript as well, Finbar sets a pattern where descriptions of experience interpenetrate with analyses and critiques of institutional presences. The section beginning and ending with a critique of the medical definition of alcoholism (Lines 21-145), for example, runs together the experience of life inside the Omagh Mental Hospital and the burdens of laboring under a diagnosis of major mental illness with a cogent critique of the hierarchy in the asylum and the deployment of the category of mental illness with which he happens to be associated in popular culture. Similarly, Finbar's rich phenomenological description of his exceptional experience of an increasingly hostile environment, "a total altering of perception" (Lines 161-76), is also preceded and set up by a description and a critique of two institutional technologies, the visit by a psychiatrist and the prescription of Largactil. 


\section{SUFFERING AND RESPONSIBILITY}

Throughout this section, Finbar also makes several rhetorical moves within what we might call the institutional channel of his diagnosis along the axes of legitimation and responsibility. First, he develops a position in a symbolic continuum of personal responsibility that questions the current status of alcoholism as "a disease entity" and therefore outside of the realm of the will. At the same time, he implies (Lines 31-32) that "the schizophrenics" (and note that this is one the very few times that Finbar uses the nominal adjective, and that this occurs only in the context of discussing interactions in the mental hospital) are "really sick" and deserving of sympathy in the way that alcoholics are not.

At the same time, Finbar is weaving in a point about social justice in this part of the story. He sees his life as so marginal, for example, that even other marginals (such as alcoholics, manic-depressives, and mental handicaps) seem to have substantially more cultural capital available to them, and he wonders why his plight generates so little sympathy in the hearts and minds of others - "We are in fact the lowest" (Line 35-36). The "we" here is marvelously ambiguous in a fashion that is incomprehensible in the absence of the appreciation of institutional authority. On the one hand, it can be read as "We = schizophrenics" because according to the institutional hierarchy as Finbar describes it, the referent group for this noun is in fact "the lowest." On the other hand, the use of the word "we" is also a refusal to use the noun form "schizophrenic" and at this level can be read as part of the resistance to this term that Finbar displays in other parts of the manuscript.

Finally, Finbar points to the abyss of hopelessness that runs alongside the life of most people diagnosed with schizophrenia in Western countries. "The attitude that people have to lunatics or schizophrenics is that they're, you know, dangerous ... horrible" (Lines 47-49). Indeed, as Finbar points out, in popular perception of mental illness in the United States and Europe, to the extent that others with major mental illnesses are dangerous or hopeless, then they are often assumed to be "a bit schizophrenic." This popular attitude finds support in rates of recovery of schizophrenia in industrialized nations being very much lower than in less industrialized ones (Warner 1985; see also Barrett 1988).

Connected to this feeling of intra-institutional inferiority is a more pervasive sense that Finbar has about always seeming to be at the wrong end of power relationships based on knowledge and authority. An enduring theme in many of our conversations, for example, was how little control he exercises over his life, indeed, even over the terms in which his life is discussed, due to his structural position. His money is provided by the 
state, his home by his father, and nearly all of his interactions - mostly clinic visits and contact with fellow sufferers through the Schizophrenia Association of Ireland - is dominated by his illness label. This feeling of structural inferiority is most keenly felt by him vis à vis psychiatry and psychiatrists. Psychotropic drugs are for Finbar a prototypical example of this helplessness. From their mode of administration (watched ingestion or injection) to their effects (tranquilization) to their side-effects (interference with volitional activities, such as involuntary muscle movements, impotence, loss of speech) they emphasize and reproduce this feeling of being overpowered.

\section{THE INTERVIEWER INTER-VIEWED}

During this initial part of the conversation, Finbar also offers the ethnographer a series of challenges concerning the injustice of his social and institutional positions in relation to the intimate connection between knowledge and authority. This critique is germane to the second theme of this work, that is the textualization of Finbar's life in the context of a knowledge-product in medical anthropology. The status of the category of alcoholism, the nature of professional and popular assessments of bipolar disorder, the status of medical knowledge more broadly, and the justice of the authority of expert knowledge as such, for example, are all the subject of comment in Lines 65-122 and again in Lines 182-223. These challenges were graded, I believe, according to his assessment of my likely reaction. The section above begins with a rhetorical question, "The alcoholics, what exactly is it?" and ends with a serious critique of the institutionalized authority of professional expertise (Lines 111-122). Finbar sustains a theme in this section (and revisits it in the next) that is essentially a broadside against the concept of "the expert," particularly the will to power of the expert based on a culturally validated claim to specialized knowledge around which certain barriers, from levels of education to technical languages, are erected and defended.

One of the reasons that Finbar textualized his experience in the way that he did is to render it impossible for me to escape the issue of his institutionalized voicelessness. I cannot help but think that his weaving together of his accounts of being engulfed by a particularly unfortunate illness label side-by-side with a critique of the institutional basis of the knowledge that undergirds the authority of this label was deliberately provocative on his part. Finbar points out the erasures upon which the institutional authority of his own diagnostic emplotment rests. These erasures include actual silence, such as Dr. MacDermot's refusal to discuss Largactil 
with him to an experience that Finbar shares with many other chronically mentally ill individuals, that is any resistance to institutional authority being constructed as a lack of insight into his illness. Finbar's tactic in this section forced me to acknowledge, if only by my own silence, a critique of knowledge-power from which my own project (a doctoral project geared in part to establishing my own expertise) could not be completely absolved.

\section{CONFLICTED PHENOMENOLOGY AND INSTITUTIONAL CONFLICTS}

After Finbar's initial reflections on the nature of the institution, he goes on to consider in more detail his first serious institutional contacts (Lines 130-222). The first thing that is apparent about this section is how Finbar tacks easily between the first time that he was given neuroleptics and his first hospitalization episode almost five years later, with only my question interrupting this flow (Lines 129-146).

Notice also the easy movement between different orders of knowledge and experience to what can only be called political critique - from contact with the technologies of the asylum (neuroleptics and visits by a psychiatrist) to an attempt to understand these technologies (the failed conversation about Largactil) to his questioning of the status of expert knowledge (i.e., Finbar's off-hand observation that doctors are very short on philosophy) (Lines 161-164). Perhaps, the most interesting aspect of this last critique is the manner in which Finbar refracts the medical handling of psychiatric patients through a reading of a scene from the New Testament that is reminiscent of Dostoyevsky's critique of mystery and authority in the scene of the returned Christ and the Grand Inquisitor (1980:227-240). The mystery that surrounds psychiatric practice and the authority that Finbar sees as flowing from this mystery comes in for severe criticism in Lines 211-220.

All these examples serve to illustrate what Foucault calls the points of confrontation in a knowledge-power setting (1980, particularly "The Two Lectures" also Foucault 1973, 1979). First, Finbar argues against what Douglas (1987:101-105) identifies as a primary form of institutional power, that is, the ability to name. Note, for example, his struggling with the nominal form "a schizophrenic" and the more grammatically ambiguous "schizophrenic" (Lines 139-141), and how the latter form eventually wins out. This grammatical slippage is followed immediately by the more folksy description of "around the bend." Next, he develops an extensive description of his altered phenomenology at that time (Lines 162-182) as a critique of what he considers to be Dr. MacDermot's inappropriate question, "Do you feel people are against you?" (Lines 153-4). This expands 
into a more general statement, "Doctors are usually very short on philosophy" (Lines 163-4), foreshadowing Finbar's extended commentary on the irrationalities of how this particular psychiatrist administers Largactil (Lines 184-223).

In this section, Finbar also problematizes the issue of the relationship between textuality and subjectivity. The section begins by Finbar acknowledging an altered sense of himself as a subject, but also by resisting the convention of this state becoming a sort of narrator ${ }^{16}$ - "I didn't actually go 'around the bend' as such. You know, I wasn't mad in the conventional sense of the word" (Lines 141-43). He then goes on to defamiliarize the psychiatrist (the character at this point of the plot with seemingly the best claim to an unproblematic subjectivity) by pointing to the strangeness of asking someone, "Do you feel people are against you?" before even saying "Hello" (Lines 154-55). He also gets a laugh at the psychiatrist's symbolic expense in speculating on the uneasy relationship between medical doctors and philosophy.

More dramatically, Finbar radically complicates MacDermot's subjectivity via a process of intertextualization, substituting Jack Palance (an actor who has made a career of being professionally inscrutable) just before critiquing the irrational secrecy that Finbar sees as surrounding psychiatric praxis (Lines 193-208). It is difficult to describe how witty was this remark "in context." Even a close transcription (which this is not) cannot do justice to the subtle metalingual markers of intonation and hand and facial gestures that framed his speech at this point and made this crossing of texts so seemingly appropriate.

Once again, however, this reading of the text that I have just presented, that is, Finbar's questioning of Largactil expanding into musings on the epistemological shortcomings of some of the psychiatrists with whom he has interacted, their association with Hollywood movie actors, finally developing into a reflection on Jesus' criticism of the relationship between mystery and authority, is itself determined by a particular interpretive stance. If I was committed to a very different institutional narrative, for example, I would very likely use the exact same fragment as an indication of such important diagnostic markers as a loosening of associations and lack of insight. But this is precisely the point. Both the production of this text and its interpretation in the context of another discourse is saturated by assumptions and practices that "set up" which of the multiplicities of meanings within it are placed in the foreground. Comparing how different discourses are "set up" in this respect forces us to examine the real social sites where power lives. Here, "power" is anything but an abstract 
entity; rather, it inheres in the production and promulgations of specific interpretations of a socially situated story.

THE SECTARIAN DIVIDE AND INSTITUTIONALIZED VIOLENCE

1977 and 1979, the years of Finbar's most serious breakdowns, separated by almost a year of hospitalization, are treated as a narrative unit in his imagination (Lines 194-415). This block of time forms an important dividing line in his life story that stands as a something of a bookend to the '66/'71 acquaintance with psychiatric technologies that, as it were, sets up his "career" as a mental patient. Again, as in the case of Dr. MacDermot, it is a technology of the asylum, in this case hospitalization, that ties together the two incidents recounted here. I have rather artificially divided up the two episodes recounted below, partly in order to comment on some aspects of a long stretch of text, partly to highlight my own mistake of asking a question about the hospital in Belfast to which Finbar had been committed in late 1977 during what I thought was a pause in the story. Finbar ignored this interruption in order to complete his sense of the episode.

However unhappy were the years 1977-1979 for Finbar, they were also very bad years for Belfast. Sectarian tensions were rampant and there were times where being on the streets as a young Catholic male was actually quite dangerous. In particular, the Shankill Butchers, a group that was composed of individuals who were part paramilitary fanatics and part serial killers, had been randomly pulling men off the streets in known Catholic areas and murdering them in a brutal and ritualized fashion in the late ' $70 \mathrm{~s}-$ an obvious worry in the life of a man in the habit of taking long walks alone in the city at night. Indeed, so random were these slayings that a couple of Protestants were killed accidentally by this gang. In any case, it was felt in many Nationalist circles at the time that the Royal Ulster Constabulary (RUC) was not diligently pursuing these cases (for a good summary of this period, see Dillon 1989).

Finbar once again begins this segment by running together different discourses about his internal phenomenology that are symbolically and politically charged. First, he gives voice to folk knowledge of exceptional states, "'round the bend" (Line 229), then to psychiatric knowledge, "schizophrenic episode" and "breakdown" (Lines 231), then to religious understandings, "the man above knows more about it" (Lines 243-245), then to his own situated knowledge about his condition (Lines 245-249), a very physiological description that he still frames as expressly invalidating the psychiatric viewpoint.

Once again, Finbar's "internal" description sets the stage for a description of external events. Finbar's narrated breakdowns in 1977 and 1979, 
for example, play in complex ways on the relationship between his internal phenomenology, that is his status as a social outsider and his experience of exceptional states of consciousness, and some of the broader issues in Belfast at that time. Thus, the institutionalized violence of The Troubles is eerily reflected in the interior landscape of an alienated young Catholic male experiencing an extraordinary state of consciousness. This seems to be less an "embodied" tension (pace Csordas 1990) than a sort of mutual scripting, where the institutionalized violence in Finbar's behavioral environment overdetermines a delusional trajectory, and the narrative of the delusion serves as a critique of the institutionalized violence. We see, for example, a very interesting movement from Finbar's own altered perception (feeling like the inside of a horror movie) to the violence in the city at large. Especially important here is the use of "it was that hostile thing again" (Lines 283-4) which knits together this part of the story and his earlier description of his difficulties. It also allows Finbar to expressly equate his perception of phenomenological "hostility" in his behavioral environment to the "concrete" hostility of The Troubles.

The power of this part of the story to move the reader/hearer (either to pathos or humor) is the result of Finbar running together critical images and different orders of knowledge in arresting ways. The vans and lorries on the road that he always sees and knows well, the bodies in the lorries which he cannot see, but whose dread he feels, the image of Hitler and the Final Solution, whose story is known to him through his interest in history, and his sense of social and personal abandonment that is an old, if unwelcome, companion are narrated on the same plane. This epistemological flattening knits together this segment drawing the reader/hearer into a peculiar world, while providing the basis of the rhetorical force of the connection between images in a disordered mind and the frightening state of the society at large whose bitter divisions can also, when viewed from the proper perspective, be the stuff of humor.

It is clear, moreover, that Finbar was very interested in precisely situating my understanding of his pushing together of these levels. Finbar's "you knows" become more frequent this part of the transcript, two of them hard on the heel on "it was that hostile thing again" (Lines 283-4). I take these "you knows" to be Finbar's hermeneutical probes to satisfy himself as to my understanding of his narrative argument comparing his disordered internal phenomenology to his institutionally disordered interactive environment, tying together his internal and external motivations. 


\section{FOOLS GO BOLDLY}

From the horror of the "Final Solution" imagery in the vans and lorries episode, we come to the narration of another florid episode (interrupted by a question on my part that Finbar pointedly ignored) that is profoundly funny. In the midst of an episodic loss of contact with "reality," Finbar manages to interact peacefully across political and sectarian divides. His "unmotivated" conversation with passers-by, his interest in the Church of one of the best known bigots in the Unionist Community, and his bizarre, if undeniably humorous interactions with British soldiers are highly charged symbolically. "I was always looking for things, I got them out" (Line 393), Finbar insists, while tacking between descriptions and critiques of various authoritative institutions, provocatively running together the history of Catholic Church, the historical growth of Great Britain as a world power, the modern British occupation of the Six Counties, and the Roman Empire.

There is real danger here for Finbar - wandering promiscuously through the unmarked but very real borders that scar the geography of Belfast, approaching nervous English troopers waving a Roman salute, reaching out across the sectarian divide with a provocative philological analysis, or unexpectedly visiting the church of another community - were not, and to some extent still are not, safe activities in which to engage in Belfast.

It is easy, then, to read this part of the story as simple "resistance," with Finbar cast in the role of the wise fool, carrying the banner of his community into an enduring colonial struggle. At times, Finbar tactically plays with this part of his life history, extracting this narrated episode for public display, particularly when his anti-psychiatric opinions get him in trouble with the predominantly family-controlled Schizophrenia Association of Ireland. As I wrote in my field notes after Finbar had a very tough time with a group of family members to whom he was making a presentation:

Finbar has a comical story of one of the times he was "around the bend" in Belfast. At the time he had developed an intense religious preoccupation which centered on this Catholic/Protestant problem. By way of explanation we might note that this episode occurred in 1979 at a very bad time in The Troubles. In any case, during this episode, Finbar felt "driven" around the city wandering through both Catholic and Protestant sections of the city throughout the night. During the middle of the next morning, he found himself at the steps of The Martyr's Church of Dr. Ian Paisley. A wedding was in progress, when Finbar goes to the doors of the church and identifies himself as a Roman Catholic to two large men in tie and tails (probably well-dressed bodyguards) at the door. He requested to "see the church." He was grabbed and hustled out the gates.

This story is funny, a ray of harmless absurdity during a time of brutal absurdity. Finbar successfully contrasted the violence of the "sane," the slaughter of people for their religious beliefs and community affiliations, to the benign befuddlement of the mad. He also successfully emphasized a unity that potentially encompassed this group (myself excepted) with 
respect to another collective, i.e. Irish Catholics as over against people who do not like Irish Catholics, successfully defusing some of the hostility that he knows his anti-psychiatric views provoke in this audience [Field Notes 1 February 1989].

This performance is effective because while there are many shades of opinion to be found in the South concerning the political situation in the North, it is a safe bet that, in any audience in the Dublin area, there will be few die-hard Ian Paisley fans. A joke at his symbolic expense, particularly a well-performed one, is rhetorically powerful.

Despite the overt political aspects embodied in this part of the fragment, Finbar's sense of the existence of power in the strange political terrain of Northern Ireland is fundamentally more complex than simple resistance would indicate. Just after this point in the interview, for example, after an off-hand comment that I canvassed before I thought of what I was saying, Finbar contemplated other aspects of the "colonial" superstructure with which he has come in contact.

$\mathrm{J}$ : Ah, the legions of the colonial state.

F: That's hard to say, now. I don't know. I wouldn't had got to university had I lived in the

5 south.

\section{$\mathrm{J}$ : Why is this?}

F: Because of the grants ... I wouldn't have got

10 the grants like - it was only because of the grants that I got from the "oppressive" British government that got me to university, you know. So, there's two sides to imperialism.

\section{J: [Laughs]}

F: There's Santa Claus and the big stick. It depends on which you get I suppose.... The only side I ever saw really, if I was honest about

British imperialism, was that I got grants out of it to go to university. And, my father had a good job in the imperialist post office.

After a long pause, Finbar completed his story.

F: So, then in '77 and '79, when I'd been around the bend, when I came back to normality, I realized 
that, I realized myself that I'd been schizophrenic

because I knew all the symptoms of schizophrenia by that time. I had been .. all through the seventies, I had been really studying. I had been reading a lot of Eysenck ${ }^{17}$ and other psychologists, and other things about psychiatry, so I knew ... I could have written a short book on psychiatry.

J: [Smiles]

F: A slightly irreverent book, mind you. But when

I came back to normality, you know, I didn't know what the hell, you know. I was mad after those three weeks in '77 and again in '79, I knew that I was a, I was schizophrenic. I said to the nurse. ... I said to the doctor, "Is it schizophrenia?"

It was a young female doctor, she said, "Yeah."

That's when I knew.

\section{INSTITUTIONAL PRODUCTIONS}

I framed my analysis of this narrative by arguing that institutional realities are produced as discursive objects in a story in such a way as to both restrict the freedom of, and give shape to, the narrative flow. It is evident, for example, that Finbar's story of "his" life bears the imprint of the power wielded by the institutions in whose orbits he has been caught. At the same time, there is clearly much more going on here than the mere working out of constraint and necessity. We have seen, for example, how Finbar's narrative has not just been restricted by the presence of institutions, as I have defined them, its own "flow" has cut into social life, uncovering institutional sediments, to use a tried and true anthropological trope, for reflection and commentary.

I do not mean by this trope of flow for one aspect of Finbar's story that there is romantic freedom innate to "narrative" in the abstract that the presence of institutions in the abstract inevitably reigns in. I do mean that Finbar's specific narrative produces specific sorts of institutional power as discursive objects and that in this process these powers then become open to examination and critique. The satirical quality of the incident with Dr. MacDermot relies on the knowledge of how power is institutionalized in psychiatric settings. Both the horror of the lorries outside of Finbar's window and the humor of his interaction with a Belfast Unionist and 
British soldiers requires a knowledge of how political power and violence are institutionalized in the Northern Ireland's sectarian conflict. This way of looking at the relationship between narrative and institution emphasizes both the undeniable creativity inherent in narration and those real power relationships that exist in the social life of narrators.

This tension between flow and constraint becomes most evident at Finbar's most agentless (and, therefore, at his seemingly most plotless) moments in the story. Even Finbar's most florid symptoms play along this boundary between the potential of narrative freedom and the presence of institutional necessity in concrete social and historical circumstances. "Justice is a Roman word!" is at once the meaningless ejaculation of a wandering schizophrenic and a motivated, provocative probe into the open sore of the sectarian divide in a city split against itself. Both its status as a delusion as well as its wry humor are predicated on an institutionalized conflict that pits sectarian communities against one another in part on the basis of religious/historical justifications. The response it elicits (and the fact that it gets an engaged response is itself telling), "Yeah, it's Roman, not Italian," in its turn forms the basis for reflection on the very conflict that helped to script the delusional comment in the first place. "He was getting in a point," Finbar generously concedes, in a very long-standing conversation in the north of Ireland.

Precisely this same quality of exposing institutional foundations imbues Finbar's conflicted anti-psychiatric annotations of a story he is generating in part with me in response to a question concerning a psychiatric illness label. Throughout this text, institutional discourses - things to be said and ways of saying them - are produced as discursive objects and then questioned by running them into one another within the narrative. Thus, Finbar deploys a vision of morality in order to critique the injustice of the relationship that he sees in psychiatry between mystery, knowledge and authority. In other places, Finbar attempts to appropriate the authority of scientific rationality to challenge what he sees to be an irrational sense of secrecy surrounding psychiatric praxis. Indeed, even the discourse of psychiatry itself is flirted with as a critical tool, when, for example, Finbar calls into question the disease status of alcoholism in order to make a point about the relationship of society to its various categories of marginals.

Despite all these maneuvers, however, at the end of the narrative Finbar is himself produced as an institutional subject - "I knew that I was a, I was schizophrenic." This production, however, is ambiguous and contested to the last, ending finally with, "Is $i t$ schizophrenia?" It is precisely this ambiguity that provides the "space" for Finbar's narrative, what makes it something other than a narrative and a quest for therapy. Within his own 
story, the institution is interrupted, as it were, in the act of its own discursive reproduction, and this interruption, woven into Finbar's narrative, provides the "space" for Finbar's critical reflections as well as for his sustained narrative development of his more floridly psychotic moments.

Note, however, this is a very different sort of "gap" than what is generally pointed to in narrative theory as the necessary conditions of a story, even an illness narrative (Mattingly 1994). The space for this narrative is not just a question of Finbar's individual desire or longing - the difference between where he is and where he wants to be, or even in the conflicts and negotiations that we presume to exist between Finbar, his family, and his various therapists. It is also crucially located in the short circuiting of a diagnostic emplotment that works on an institutional logic of being able to define and to silence - that there are things to say and ways of saying them. We can only know this aspect of the "story" by knowing something outside of the conventional sense that we assign to the notion of "narrative." Therefore, I have argued for the inclusion of what I have called the institutional landscape upon which the story as such is grounded as part of any theory of narrative. My logic in using the trope of "landscape" comes from the fact that the image is complementary to the metaphor of "flow" through which we often understand narrative. Just as a river cuts into and exposes to view parts of the very bank that makes the river itself possible, so, too, do we need to consider the teller of this story and the institutional topography he is narrating as parts of one conceptual whole.

\section{CONCLUSION}

As far back as Hegel, Hayden White reminds us, narrativity has required a sense of law and social order. At least, for the discipline of history, White argues, law provides the substrate upon which narrative can invoke and reproduce a sense of authority. It is on this basis that the meaning of events, their didactic qualities, ultimately the point of an historical narrative can be debated. Thus, White rather provocatively concludes that there can be no narrating without moralizing (White 1981:22-23).

There is another aspect to this understanding of narrative that White does not explore in any great detail. To the extent that many voices narrate, stories also contain the possibility of exposing the silences and erasures of the symbolic violence from which, following Bourdieu, the law itself derives legitimacy (Bourdieu 1991). Finbar's text has just this quality. It voices the silences and plays with the erasures that undergird the practices and discourses of institutional psychiatry, in particular, and other institutions as well. Thus, Finbar can spin out this story only because he exists 
after a particular historical moment where he has been emplotted in a particular fashion that he is in part resisting.

Such considerations, however, clearly lead us back to the other theme that I proposed in the beginning of this work, that is, how the institutional preconditions that both constrain and constitute the sub-discipline of medical anthropology provide us our own means of narrative production. I have, for example, retextualized a portion of an interview manuscript that seems to me to possess a certain coherence in the telling within another genre, the academic paper, that is not innocent of some of the critiques concerning the issue of authority and appropriation of voice that Finbar levels at psychiatry. This appropriation is the most distressing personal and theoretical problem in this analysis. Part of this problem is located in the nature of representation itself. The world calls for words, but any particular phenomenon always eludes its complete description. As Alan Young has pointed out in the case of Posttraumatic Stress Disorder, it is not a question of the assignation of names to states of exceptional, or even ordinary, experience around which conflict takes place. There are no end of names for things. It is the ability to silence other names, erase other knowledges, through a claim to symbolic-political-expert authority, that is the locus of real struggle in most of the settings in which we are interested (Young 1990).

Therefore, I have argued that the narrative and the silences configure, even entail, one another and that both are set up by specific institutional configurations. Thus, I have tried to open up a wider theoretical space for the concept of institution than is common in much of narrative analysis. I hope that this sense of institution has provided insight into the conditions of the production of this particular narrative, as well as pointing to the usefulness of a more explicit focus on institutions in the development of a general theory of narrative in medical anthropology that will continue to generate interesting research questions. ${ }^{18}$

A. Jamie Saris

Department of Anthropology

St. Patrick's College

Maynooth, Ireland

1. One can read some of the tropic concerns that developed in anthropology in $1970 \mathrm{~s}$ (e.g., Turner's concern with symbolic/ritual process, Fernandez's interest in arguments with images) as containing some of the seeds of this narrative concern in the discipline.

2. "T and F" is most likely derived from the nineteenth-century British colonial designation of the place, "The Tyrone-Fermanagh District Lunatic Asylum." 
3. RTE is the acronym for Rádio Telefis Érin.

4. A program on the $\mathrm{BBC}$ dealing with recent biomedical advances in delineating bipolar disorder. It also focussed on the creativity of many people afflicted with this disorder.

5. Finbar's 1971 hospitalization was in St. Patrick's Hospital in Dublin, a private hospital for which his father was willing to pay to avoid the local stigma of having a locallyknown case of mental illness in the family.

6. The date we met, after his presentation at the SAI meeting.

7. After almost eleven months of hospitalization.

8. A multi-part article over several weeks in the Times, detailing experiences, family burdens, and recent biochemical research into schizophrenia.

9. Ian Paisley, the radical leader of the Democratic Unionist Party. He is one of the most brazenly anti-Catholic leaders of the constitutional Unionist parties.

10. The exact quote is "Britain is a world by itself; and we will nothing pay for wearing our own noses" (Cymberline: Act III, Scene 1).

11. Barriers composed of concrete blocks, corrugated iron, and razor wire, used by the British Army and the RUC to restrict access between various parts of the city.

12. My usage of the word "channel" in this context is slightly different from that found in other works concerned with textual analysis. In these works, "channel" refers to types or media in which texts are expressed,i.e., how the formal properties of a textual mode, painting, poetry, etc., condition the nature of the text (Hanks 1989:101). Instead, I will take a different, perhaps even naive, view of channel in this work, looking at how the narrative flow is interrupted or shifted within this particular text, that is, where the narrator encounters oppositions or obstacles as part of the development of the story.

13. There may be an important distinction to make between therapeutic and diagnostic emplotment. Schizophrenia is a category where this distinction may be particularly $\grave{a}$ propos as modern psychiatry defines the ability to recover more and more out of the category as such.

14. A temporal definition of disability and the concept of "emplotment" as I am using it here merges with Goffman's observation of thirty years ago that a mental patient embarks upon a "career" as part and parcel of a diagnosis of mental disorder and his or her official entry into the technologies associated with the asylum (Goffman 1961; see also Estroff 1993:259).

15. Teach mór in Gaelic can mean a large mansion as well as a mental hospital.

16. First person accounts of mental illness often use this convention of the "mad me" in retrospective narratives (see, for example, North 1987)

17. For a popular example of the work of the psychologist H.J. Eysenck, see Eysenck 1972.

18. This research was made possible by support from The American Council of Leamed Societies and the Social Science Research Council Doctoral Research Program for Western Europe (1988-1990). Early drafts of this paper benefited from my interaction with the Medical Anthropology Seminar of the Department of Social Medicine at Harvard Medical School where I was a Fellow in the Program for Clinically Relevant Medical Anthropology (1992-1994) funded by the National Institute for Mental Health and from feedback from the Department of Anthropology at the University of California at Santa Cruz where I presented this data in the Winter of 1994. Finally, I would like to extend particular thanks to those who read various versions of this work and provided helpful comments, particularly Arthur Kleinman, Byron Good, and Robert Desjarlais. 


\section{REFERENCES}

Abu-Lughod, Lila

1993 Writing Women's Words: Bedouin Stories. Berkeley: University of California Press.

Bakhtin, M.M. (Holquist, M. trans.)

1981 The Dialogic Imagination: Four Essays. Austin: University of Texas Press.

Barrett, Robert

1988 Interpretations of Schizophrenia. Culture, Medicine, and Psychiatry 12:357-88.

Baumann, Richard, and Charles Briggs

1990 Poetics and Performance as Critical Perspectives on Language and Social Life. In Annual Review of Anthropology 19:59-88.

Bourdieu, Pierre

1984 Distinction: A Social Critique of the Judgement of Taste. Cambridge, MA: Harvard University Press.

1991 Language and Symbolic Power. Cambridge, MA: Harvard University Press.

Bruner, Jerome

1986 Actual Minds, Possible Worlds. Cambridge, MA: Harvard University Press.

Clifford, James, and George Marcus (eds.)

1986 Writing Culture: The Poetics and Politics of Ethnography. Berkeley: University of California Press.

DelVecchio Good, Mary-Jo, Tsunetsugu Munakata, Yasuki Kobayashi, Cheryl Mattingly, and Byron J. Good

1994 Oncology and Narrative Time. Social Science and Medicine 38:6:855-872.

Derrida, Jaques

1978 Writing and Difference. Chicago: University of Chicago Press.

1981 The Law of Genre. In On Narrative. W.I.T. Mitchell. Chicago: University of Chicago Press.

Dillon, Martin

1989 The Shankill Butchers: A Case Study of Mass Murder. London: Hutchins.

Dostoyevsky, Fyodor (Garnett, C. trans.)

1980 The Brothers Karamazov. New York: The New American Library.

Douglas, Mary

1987 How Institutions Think. Syracuse, NY: Syracuse University Press.

Estroff, Sue

1981 Making It Crazy: An Ethnography of Psychiatric Patients in an American Community. Berkeley: University of Califomia Press.

1993 Identity, Disability, and Schizophrenia: The Problem of Chronicity. In Knowledge, Power, and Practice: The Anthropology of Medicine and Everyday Life. Shirley Lindenbaum, and Margaret Lock, eds. Berkeley: University of California Press.

Eysenck, H.J.

1972 Psychology is About People. Suffolk: Richard Clay.

Fernandez, James W.

1986 Persuasions and Performances: The Play of Tropes in Culture. Bloomington: Indiana University Press.

Foucault, Michel

1973 Madness and Civilization. New York: Vintage Books.

1979 Discipline and Punish: The Birth of the Prison New York: Vintage Books. 
1980 Power/Knowledge: Selected Interviews and Other Writings, 1972-1977 [C. Gordon ed.]. New York: Pantheon.

Frye, N.

1957 Anatomy of Criticism. Princeton: Princeton University Press.

Gaines, Atwood

1979 Definitions and Diagnoses. Culture, Medicine, and Psychiatry 3:381-418.

Goffman, Erving

1961 Asylums. New York: Harmondsworth.

Good, Byron

1994 Medicine, Rationality, and Experience. Cambridge: Cambridge University Press. Good, Byron, and Mary-Jo DelVecchio Good

1994 In the Subjunctive Mode: Epilepsy Narratives in Turkey. Social Science and Medicine 38:6:835-844.

Hanks, William F.

1989 Text and Textuality. In Annual Review of Anthropology 18:95-127.

Isaac, Rael, and Armat, Virginia

1990 Madness in the Streets: How Psychiatry and the Law Abandoned the Mentally Ill. New York: Free Press.

Iser, Wolfgang

1978 The Act of Reading: A Theory of Aesthetic Response. Baltimore: Johns Hopkins University Press.

Kleinman, Arthur

1980 Patients and Healers in the Context of Culture: An Exploration of the Borderland Between Anthropology, Medicine, and Psychiatry. Berkeley: University of California Press.

1988a Rethinking Psychiatry: From Cultural Category to Personal Experience. New York: Free Press.

1988b The Illness Narratives: Suffering, Healing, and the Human Condition. New York: Basic Books.

Kleinman, Arthur, and Joan Kleinman

1991 Suffering and Its Professional Transformation: Towards an Ethnography of Interpersonal Experience. Culture, Medicine, and Psychiatry 15(3):275-301.

Kondo, Dorine

1993 Crafting Selves: Power, Gender, and Discourses of Identity in a Japanese Workplace. Chicago: University of Chicago Press.

Laing, R.D.

1967 The Politics of Experience. New York: Ballantine Books.

Lyotard, Jean-François

1984 The Postmodern Condition: A Report on Knowledge. Manchester. Manchester University Press.

Lindenbaum, Shirley, and Margaret Lock, eds.

1993 Knowledge, Power, and Practice: The Anthropology of Medicine and Everyday Life. Berkeley: University of California Press.

Mattingly, Cheryl

1994 The Concept of Therapeutic Emplotment. Social Science and Medicine 38:6:811822. 
Marcus, George, and Michael Fischer

1986 Anthropology as Cultural Critique. Chicago: University of Chicago Press.

Mattingly, Cheryl, and Linda Garro

1994 Introduction. Social Science and Medicine 38:6:771-74.

Mishler, Elliot

1986a The Discourse of Medicine: Dialectics of Medical Interviews. Norwood, NJ: ABLEX.

1986b Research Interviewing: Context and Narrative. Cambridge: Harvard University Press.

Mitchell, W.J.T.

1981 On Narrative. Chicago: University of Chicago Press.

North, Carol

1987 Welcome Silence: My Thiumph Over Schizophrenia. New York: Simon and Schuster.

Rhodes, Lorna

1984 This Will Clear Your Mind: The Use of Metaphors For Medication in Psychiatric Settings. Culture, Medicine, and Psychiatry 8:49-70.

1991 Emptying Beds: The Work of an Emergency Psychiatric Unit. Berkeley: University of Califomia Press.

Ricoeur, Paul

1981 Narrative Time. In On Narrative. W.J.T. Mitchell. Chicago: University of Chicago Press.

1984 Time and Narrative: Volume I. (trans. Mclaughlin, M., and David Pellauer) Chicago: University of Chicago Press.

Roth, Martin, and Kroll, Jerome

1986 The Reality of Mental Illness. Cambridge: Cambridge University Press.

Saris, A. Jamie

1994 The Proper Place for Lunatics: Asylum, Person, and History in a Rural Irish Community. Ph.D. Dissertation. The University of Chicago.

Turner, Victor, and Jerome Bruner, eds.

1986 The Anthropology of Experience. Urbana and Chicago: University of Illinois Press.

Wamer, Richard

1985 Recovery From Schizophrenia: Psychiatry and Political Economy. London: Routledge and Kegan Paul.

White, Hayden

1981 The Value of Narrativity in the Representation of Reality. In On Narrative. W.J.T. Mitchell. Chicago: University of Chicago Press.

Young, Alan

1990 Moral Conflicts in a Psychiatric Hospital Treating Combat-related Posttramautic Stress Disorder (PTSD). In Social Science Perspectives on Medical Ethics. George Weisz, ed. pp. 65-82. Dordrecht: Kluwer. 